\title{
Northern Frisian Language
}

National Cancer Institute

\section{Source}

National Cancer Institute. Northern Frisian Language. NCI Thesaurus. Code C153921.

A part of the larger group of the West Germanic Frisian languages, spoken in the North Frisia area of Germany. 